\title{
Teaching NeuroImages: Early imaging of sulfite oxidase deficiency mimics severe hypoxic ischemic encephalopathy
}

Carly Scramstad, MD, Hayley Moffatt, MD, and Mubeen F. Rafay, MBBS

Neurology ${ }^{\circledR}$ 2020;95:e1913-e1914. doi:10.1212/WNL.0000000000010258

Figure MRI and magnetic resonance spectroscopy (MRS) in a 4-day-old term infant
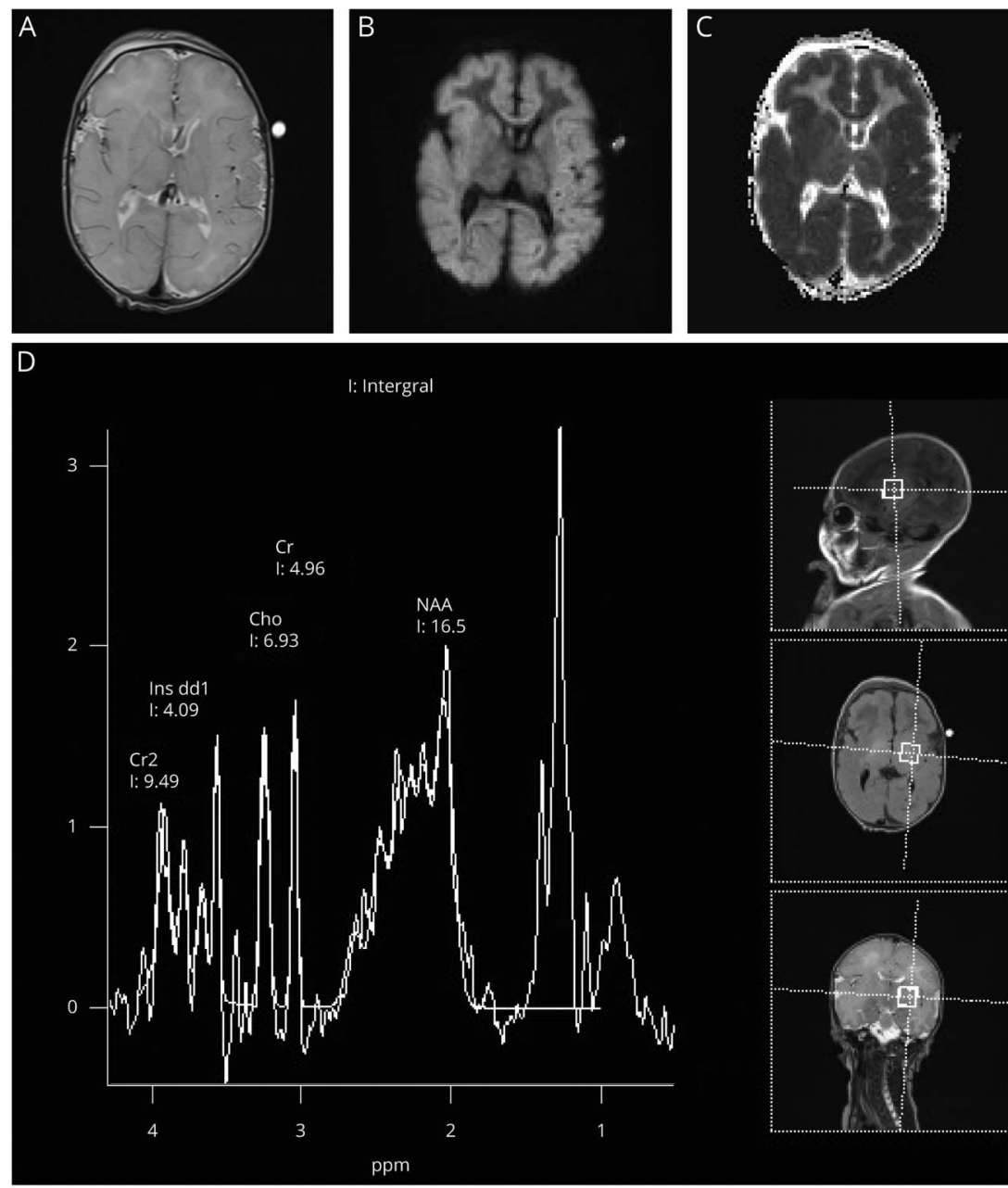

(A) Axial T2 shows cortical swelling with decreased gray-white differentiation. (B) Axial diffusion-weighted imaging shows abnormal increased signal in the cortex, basal ganglia, thalami, and corpus callosum with (C) associated decreased signal on apparent diffusion coefficient. (D) MRS, obtained over the left basal ganglia, demonstrates an elevated lactate peak.

\author{
Correspondence \\ Dr. Scramstad \\ carly.scramstad@ \\ mail.utoronto.ca
}

MORE ONLINE

$\rightarrow$ Teaching slides

links.lww.com/WNL/B164

From the Department of Internal Medicine, Section of Neurology (C.S.), Department of Diagnostic Imaging (H.M.), and Department of Pediatric and Child Health, Section of Pediatric Neurology (M.F.R.), University of Manitoba, Winnipeg, Canada.

Go to Neurology.org/N for full disclosures. Funding information and disclosures deemed relevant by the authors, if any, are provided at the end of the article. 
A term baby, with uncomplicated pregnancy and delivery, developed intractable multifocal seizures on day 3 of life. EEG showed frequent multifocal electrographic and electroclinical seizures. MRI brain demonstrated diffuse diffusion restriction (figure). Metabolic investigations revealed elevated urine sulfocysteine, reduced plasma cysteine and homocysteine, and normal plasma uric acid. CSF lactate was elevated. The diagnosis was consistent with isolated sulfite oxidase deficiency, with normal plasma uric acid differentiating this from molybdenum cofactor deficiency. The patient underwent confirmatory genetic testing. Sulfite oxidase deficiency is an autosomal recessive inherited inborn error of metabolism without treatment. ${ }^{1,2}$ Initially, it may mimic profound hypoxic ischemic encephalopathy.

\section{Study funding}

No targeted funding reported.

\section{Disclosure}

The authors report no disclosures relevant to the manuscript. Go to Neurology.org/N for full disclosures.

\section{Appendix Authors}

\begin{tabular}{lll}
\hline Name & Location & Contribution \\
\hline $\begin{array}{l}\text { Carly } \\
\text { Scramstad, MD }\end{array}$ & $\begin{array}{l}\text { University of } \\
\text { Manitoba, } \\
\text { Winnipeg }\end{array}$ & $\begin{array}{l}\text { Preparation of case report, drafting } \\
\text { and revision for intellectual content }\end{array}$ \\
\hline $\begin{array}{l}\text { Hayley } \\
\text { Moffatt, MD }\end{array}$ & $\begin{array}{l}\text { University of } \\
\text { Manitoba, } \\
\text { Winnipeg }\end{array}$ & $\begin{array}{l}\text { Preparation of figure, drafting and } \\
\text { revision for intellectual content }\end{array}$ \\
\hline $\begin{array}{l}\text { Mubeen Rafay, } \\
\text { MBBS }\end{array}$ & $\begin{array}{l}\text { University of } \\
\text { Manitoba, } \\
\text { Winnipeg }\end{array}$ & $\begin{array}{l}\text { Conceptualization, drafting and } \\
\text { revision for intellectual content }\end{array}$ \\
\hline
\end{tabular}

\section{References}

1. Claerhout H, Witters P, Regal L, et al. Isolated sulfite oxidase deficiency. J Inherit Metab Dis 2018;41:101-108.

2. Relinque B, Bardallo L, Granero M, Jimenez PJ, Luna S. Isolated sulfite oxidase deficiency. J Neonatal Perinatal Med Epub 2015 Mar 10. 


\section{Neurology}

\section{Teaching NeuroImages: Early imaging of sulfite oxidase deficiency mimics severe hypoxic ischemic encephalopathy}

Carly Scramstad, Hayley Moffatt and Mubeen F. Rafay

Neurology 2020;95;e1913-e1914 Published Online before print July 9, 2020

DOI 10.1212/WNL.0000000000010258

\section{This information is current as of July 9, 2020}

\section{Updated Information \& Services}

References

Subspecialty Collections

Permissions \& Licensing

Reprints including high resolution figures, can be found at: http://n.neurology.org/content/95/13/e1913.full

This article cites 1 articles, 0 of which you can access for free at: http://n.neurology.org/content/95/13/e1913.full\#ref-list-1

This article, along with others on similar topics, appears in the following collection(s):

Metabolic disease (inherited)

http://n.neurology.org/cgi/collection/metabolic_disease_inherited MRI

http://n.neurology.org/cgi/collection/mri

Neonatal

http://n.neurology.org/cgi/collection/neonatal

Neonatal seizures

http://n.neurology.org/cgi/collection/neonatal_seizures

Information about reproducing this article in parts (figures,tables) or in its entirety can be found online at:

http://www.neurology.org/about/about_the_journal\#permissions

Information about ordering reprints can be found online:

http://n.neurology.org/subscribers/advertise

Neurology ${ }^{\circledR}$ is the official journal of the American Academy of Neurology. Published continuously since 1951, it is now a weekly with 48 issues per year. Copyright (O) 2020 American Academy of Neurology. All rights reserved. Print ISSN: 0028-3878. Online ISSN: 1526-632X.

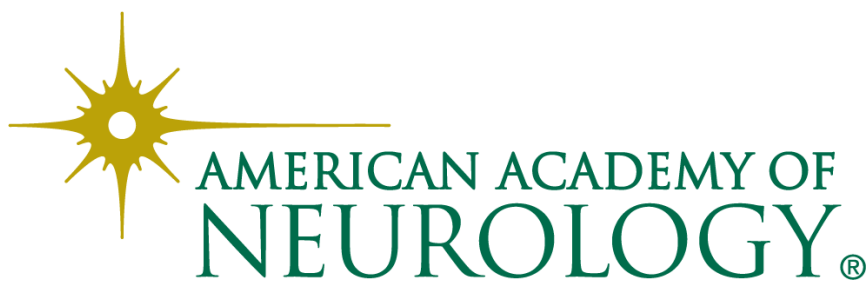

